\title{
LINGUOEMOTIVE MODELLING OF EPIGRAPHS IN THE POSTMODERN TEXT BY JOHN FOWLES \\ (on material of the novel The French Lieutenant's Woman)
}

\author{
Storchak Maria
}

Postgraduate Student

ORCID ID 0000-0003-4884-1055

Vasyl Karazin Kharkiv National University

4, pl. Svobody, Kharkiv, 61077, Ukraine

storchak.maria@gmail.com

This article deals with the problem of the design of the linguoemotive model of the epigraphs of a postmodern text. The research object is a postmodern text, the research subject is the linguoemotive models of epigraphs in modern English literary discourse. The material of the research is the postmodern novel The French Lieutenant's Woman by John Fowles. The research methodology is based on the anthropocentric paradigm in the framework of communicative linguistics. Modelling is a process of the design and application of models. The aim of text modelling is to analyse and describe transfer, perception and interpretation of texts and situations verbally and non-verbally. Linguoemotive modelling of a postmodern text can be characterized as fragmented, incomplete, having different levels of generalization and interpretation. A situational emotive component that is presented linguistically enhances the sense of a text. The specificity of the novel The French Lieutenant's Woman by John Fowles consists in emotively loaded epigraphs. Interaction of a text and a situation on the basis of emotionmodified propositions reflects the author's idiostyle.

Keywords: epigraph, idiostyle, linguoemotive modelling, model, text.

\section{ЛІНГВОЕМОТИВНЕ МОДЕЛЮВАННЯ ЕПІГРАФІВ В ПОСТМОДЕРНІСТСЬКОМУ ТЕКСТІ ДЖОНА ФАУЛЗА (на матеріалі роману «The French Lieutenant's Woman»)}

\section{Сторчак Марія}

Аспірант кафедри англійської філології

ORCID ID 0000-0003-4884-1055

Харківський національний університет імені В. Н. Каразіна пл. Свободи, 4, м. Харків, 61077, Україна storchak.maria@gmail.com

У статті розглядається проблема побудови лінгвоемотивної моделі епіграфів постмодерністського тексту. Об'єктом дослідження є постмодерністський текст, а предметом дослідження виступають лінгвоемотивні моделі епіграфів в сучасному англомовному художньому дискурсі. Матеріалом дослідження слугує постмодерністський роман Джона Фаулза «Жінка франиузького лейтенанта» (Тhе French Lieutenant's Woman). Методологія дослідження базується на антропоцентричній парадигмі в рамках комунікативного напряму лінгвістики. Під моделюванням розуміється проиес побудови $i$ застосування моделей. Метою моделювання тексту $\epsilon$ аналіз та опис прочесу передачі, сприйняття та інтерпретації художнього тексту і ситуацій через вербальні й невербальні засоби. Лінгвоемотивне моделювання постмодерністського тексту характеризується фрагментарністю, неповнотою, різним рівнем узагальнення та інтерпретації.

(C) Storchak M., 2020 
Емотивний компонент ситуащії, представлений лінгвістичними засобами, розщирює смисл тексту. Специфіка роману Джона Фаулза The French Lieutenant's Woman полягає в використанні емотивно навантажених епіграфів. Взаємодія тексту $i$ ситуації з використанням модифікованих емоціями епіграфів відображає ідиостиль aвтора.

Ключові слова: епіграф, ідиостиль, лінгвоемотивне моделювання, модель, текст.

Моделювання як метод пізнання знайшло широке застосування в наукових дослідженнях 3 двох причин: модель дозволяє, по-перше, описати оригінал і, подруге, створити менш складний, ніж оригінал, об'єкт. У лінгвістичних дослідженнях моделювання об'єктів надає можливість вийти за межі безпосередньо даної інформації при вивченні мовленнєвих, мовних i комунікативних явищ. Під моделюванням розуміється процес побудови, вивчення й застосування моделей [1, с. 146]. Завданням моделювання тексту є аналіз і опис процесу передачі, сприйняття й інтерпретації інформації за допомогою вербальних і невербальних засобів.

Мета статті полягає в проведенні наукової розвідки в теорію побудови базової лінгвоемотивної моделі тексту. Актуальність статті обумовлена розширенням об'єктів лінгвістики й посиленням ролі моделювання в лінгвістичних дослідженнях.

Об'єктом є текст, а предметом - лінгвоемотивні моделі художнього тексту. Одиницею аналізу є епіграф, що кодує зміст у тексті. Для досягнення поставленої мети в роботі вирішуються наступні завдання: лінгвістичний і семантичний аналіз епіграфів, розширення змісту тематичної мовленнєвої ситуації, лінгвоемотивне моделювання тексту з використанням епіграфа.

Матеріалом дослідження $є$ роман англійського письменника-постмодерніста Джона Фаулза (1926-2005) The French Lieutenant's Woman.

Методологія дослідження базується на антропоцентричній парадигмі в рамках комунікативного напрямку лінгвістики. Текст роману розглядається як художня комунікація.

Поліпарадигмальність уявлень про природу моделювання в гуманітарних науках і велика різноманіття досліджуваних об'єктів ускладнюють визначення поняття моделі. У дослідженнях П. М. Денисова приводиться кілька значень терміна «модель»: 1) модель як синтаксичний малюнок фрази; 2) модель як дедуктивна система; 3) модель як допоміжна мова, створена для якої-небудь специфічної мети; 4) модель як інтерпретація формальної системи; 5) модель як подібність предмета в якому-небудь масштабі. Ці визначення моделі можуть застосовуватися в усіх галузях науки [5, с. 113-114].

У лінгвістичному аспекті термін «модель», можливо, уперше, ужив 3. Херріс для позначення результатів описової методології Е. Сепіра. У мовознавстві під моделлю розуміється абстрактне поняття еталона або зразка якої-небудь системи, представлення самих загальних характеристик якого-небудь мовного явища, загальна схема опису системи мови або якої-небудь ії підсистеми [8, с. 25]. Модель, за визначенням В.В. Богуславської, це матеріальний або представлений у мисленні об'єкт, який у процесі дослідження заміщає об'єкт-оригінал, а його безпосереднє вивчення дає нові знання про об'єкт-оригінал [1, с. 146, 147]. У монографії М. Ю. Олешкова «Моделювання комунікативного процесу» під моделлю розуміється схема процесу (явища) як інваріант, де модель припускає реалізацію всіх можливих конфігурацій у прагматичному й потенційному аспектах $[10$, с. 43]. Суб'єкт діяльності, як відзначає Р. М. Фрумкіна, будує модель навколишнього світу, де слово “модель” підкреслює, що людина має справу не з копією світу, а з перетворенням вхідних сигналів, що адаптуються до потреб людини [12, с. 96]. Під моделлю розуміється узагальнена, формалізована структура або процес і спосіб опису «механізму» мови [10, с. 63].

Проблема відношення мови й емоцій привернула пильну увагу лінгвістів у другій половині XX-го століття у зв'язку з появою антропоцентричної парадигми. Проблема 
емоцій у мові обгрунтована теоретично в роботах вітчизняних та іноземних дослідників. Ми використовуємо в цій роботі методологію Я. О. Волкової (2014) [3; 4], В. О. Самохіної (2017) [11], В. І. Шаховського (2008, 2010, 2016) [13-16] і Дж. Лакоффа (2016) [18].

У нашому дослідженні моделювання лінгвістичного об'єкта містить у собі аналіз і синтез його формальної й емоційної складових. При моделюванні емотивного аспекту комунікативної ситуації в тексті художньої літератури оцінюються, як пропонує Я. О. Волкова, умови спілкування й параметри комунікації [3], використовувані для класифікації ситуацій спілкування. До умов спілкування відносимо місце, час і склад комунікантів. До параметрів комунікації належать комунікативна установка, комунікативна мета або комунікативний намір, характер спілкування, набір вербальних і невербальних засобів, реакція адресата й адресанта. Під комунікативною установкою ми розуміємо внутрішню афективну орієнтацію, що залежить від минулого досвіду, яка могла б пояснити дії особистості [2, с. 45].

У досліджуваному романі Джона Фаулза процеси комунікації розвертаються в 1860-ті роки на південному сході Англії. Процес комунікації, як відзначає В. А. Маслова, піддається сегментації [9, с. 17]. Сегментом комунікації визнаний комунікативний акт, що включає в себе дві складові - ситуацію й дискурс. Під ситуацією розуміється фрагмент об'єктивно існуючої реальності, частиною якої може стати вербальний акт [9, с. 17]. Під текстом розуміється об'єднана смисловим зв'язком послідовність знакових одиниць, основними властивостями якої є зв'язність і цілісність [17, с. 507], а під простором тексту - модель семіосфери як семіотичної моделі миру, закріпленої в даній культурі, як відзначає Ю. М. Лотман [7, с. 136]. Досліджувати текст означає досліджувати культуру, соціокультурні фактори й індивідуальні особливості автора тексту.

Роман Джона Фаулза включає 61 главу й 80 епіграфів, що запозичені з наукових праць Ч. Дарвіна, К. Маркса, К. Ліннея, статистичних звітів, текстів газет ХІХ-го сторіччя, поетичних збірників Т. Гарді, А. Теннісона, А. Х. Клафа, прози Джейн Остін та ін. У цій роботі ми розглядаємо лінгвоемотивне моделювання тексту роману на прикладі епіграфів як вихідних текстологічних одиниць. Метою епіграфа $є$ розгорнуте вираження мовної ситуації, у якій розвертається описана автором дія [6].

У першому розділі початковим елементом роману $є$ епіграф, представлений першою строфою вірша «Загадка» (The Riddle) англійського поета Томаса Гарді (Thomas Hardy (1840-1928)):

Stretching eyes west Over the sea, Wind foul or fair, Always stood she Prospectimpressed; Solely out there Did her gaze rest, Never elsewhere Seemed charm to be [19, c. 1].

Перша строфа вірша Томаса Гарді, який сповідує агностичний світогляд і якого називають попередником модернізму, звучить як філософська лірика й не дає ніякого уявлення про те, у якому напрямку буде розбудовуватися сюжет роману. Томас Гарді народився в графстві Дорсет на південному заході Англії й присвятив багато своїх творів опису природи й людей, які проживають у цьому регіоні, тому, не дивно, що Джон Фаулз обрав у якості епіграфа написаний у вікторіанську епоху вірш. Читач доходить висновку, що це експозиція вірша, тобто та його частина, яка не дає уявлення про подальший розвиток сюжету вірша.

Епіграф синтезується з наступним текстом роману таким чином, що зв'язок змісту епіграфа зі змістом роману починає прояснюватися наприкінці першого розділу: the other figure on that somber, curving mole. It stood right at the seawardmost end... . Its clothes were dark. The wind moved them, but the figure stood motionless, staring out to sea, more like a living memorial to the drowned, a figure from myth, than any proper fragment of the petty provincial day [19, с. 3] («друга фігура на тому похмурому вигнутому молі. Вона стояла прямо на самому краю .... ÏIї одяг був темного кольору. Вітер роздував його, але фігура не рухалась, вдивляючись у море, що було більше 
схоже на монумент тим, хто потонув, на фігуру 3 міфу, а не на якийсь-там характерний фрагмент звичайного провінційного дня». - переклад мій). У другому розділі, Ернестина, одна з героїнь роману, називає цю фігуру жінкою французького лейтенанта (the French lieutenant's woman), і знову автор описує зосереджений погляд жінки і сильний порив вітру: her stare was aimed like a rifle at the farthest horizon. There came a stronger gust of wind [19, с. 7]. У читача виникає асоціація, яка пов'язує персонажа епіграфа 3 персонажем роману - таємничою фігурою (figure), яку звати Сара Вудраф. В епіграфі вживаються займенник she (вона) і фрази stretching eyes west (спрямувавши погляд на захід), her gaze (iï пильний погляд), що пояснюють емоційний стан персонажа епіграфа - prospect-impressed (вражена простором) і never elsewhere seemed charm to be ( здається, що ніде ніколи не було нічого чарівного). В епіграфі закодований зміст частини роману.

Проаналізуємо епіграф і наступний текст першого й другого розділів з метою створення лінгвоемотивної моделі 1 , виклавши умови спілкування й параметри комунікації [4].

Умови спілкування: 1) місце - містечко на південному сході Англії; 2) час - 1867 рік; 3) склад комунікантів - автор і читач.

Параметри комунікації:

1.Комунікативна установка читача: знання поезії (творчості Томаса Гарді) i філософії.

2.Комунікативна мета (комунікативний намір) автора: кодування змісту наступного тексту за допомогою категорій «очікування», «напруга», «самотність» $\mathrm{i}$ «розчарування».

3.Характер спілкування: нейтральний і неформальний, опис події й внутрішнього світу дівчини.

4.Вербальні засоби: вірш 19-го століття на 9 рядків, рима, складне і два прості речення $з$ емфазою.

5.Невербальні засоби: епіграф є розміщеним посередині аркуша, зберігаючи форму вірша, по 2-4 слова в рядку.

6.Реакція адресата: пригноблений стан після прочитання вірша - останнє речення епіграфа має негативно заряджений емоційний зміст.

7.Реакція адресанта: текст вбирає в себе вірш Томаса Гарді за допомогою прямого цитування, автор запрошує Т. Гарді в співавтори - відбувається розширення тексту роману за рахунок епіграфічного тексту.

Сара Вудраф, головна героїня роману, яку за глаза називають жінкою французького лейтенанта, скомпрометувала себе зустрічами iз французом, викликаючи осуд громадськості. Француз покинув Англію, а Сара постійно ходить на набережну, марно очікуючи побачити судно, на якому повернеться ії коханий. Тема епіграфічного тексту - туга самотньої жінки. Тема макротексту бере початок у мікротексті, тобто тема роману Джона Фаулза бере свій початок в епіграфі Томаса Гарді. Ситуація вірша входить до складу подій роману, створюючи єдиний простір двох творів - тексту, написаного Джоном Фаулзом, і тексту, написаного Томасом Гарді.

Другий розділ містить два епіграфи. Перший епіграфічний текст є прозою:

In that year (1851) there were some 8,155,000 females of the age of ten upwards in the British population, as compared with 7,600,000 males. Already it will be clear that if the accepted destiny of the Victorian girl was to become a wife and mother, it was unlikely that there would be enough men to go round. (E. Royston Pike, Human Documents of the Victorian Golden Age) [19, c. 4].

Проаналізуємо перший епіграф другого розділу і наступний за ним текст другого розділу із метою створення лінгвоемотивної моделі 2, виклавши параметри комунікації, оскільки умови спілкування залишаються без змін.

Параметри комунікації:

1.Комунікативна установка читача: знання соціології й історії. 
2.Комунікативна мета (комунікативний намір) автора: кодування змісту наступного тексту, використовуючи соціологічні дані про співвідношення дорослих чоловіків і жінок у Великобританії в 1851 році.

3.Характер спілкування: формальний факт, опис демографічної ситуації.

4.Вербальні засоби: офіційно-діловий стиль, два складних речення, дані по народонаселенню.

5.Невербальні засоби: епіграф розміщений посередині аркуша.

6.Реакція адресата: нейтральний емоційний стан при одержанні інформації про те, що у Великобританії в 1851 році кількість жінок старших за 10 років перевищувала кількість чоловіків на 555,000 осіб.

7.Реакція адресанта: автор знайомить читача 3 реальною демографічною ситуацією.

Тема першого епіграфа другого розділу виражена на лінгвоемотивному рівні як двозначність становища дівчат: роль матері й дружини, з одного боку, і неможливість вступити в законний шлюб, з іншого боку.

Другий епіграф другого розділу представлений строфою з народної пісні:

I'll spread sail of silver and I'll steer towards the sun,

I'll spread sail of silver and I'll steer towards the sun,

And my false love will weep, and my false love will weep,

My false love will weep for me after I'm gone. (West country folksong: "As Sylvie Was Walking") [19, c. 4].

Лінгвоемотивна модель 3 представлена параметрами комунікації:

1.Комунікативна установка читача: знання народної творчості.

2.Комунікативна мета (комунікативний намір) автора: кодування змісту за допомогою епіграфа: парубок щезнув на кораблі, залишивши подружку.

3.Характер спілкування: неформальний.

4.Вербальні засоби: строфа 3 народної пісні, два прості речення повторюються двічі, одне просте речення - тричі.

5.Невербальні засоби: епіграф є розміщеним посередині аркуша у форматі пісні.

6.Реакція адресата: емпатія до дівчини, яку залишив парубок.

7.Реакція адресанта: відображення ситуації роману у рамках однієї строфи.

Сара Вудраф, яку залишив французький офіцер, стоїть на самому краї пірса під небезпечними поривами вітру, неначе уособлюючи тему третього епіграфа - сумну доля тих дівчат, які приймають несерйозний статус подружки, оскільки згодом вони гірко шкодують про свій вчинок.

Автор використовує два епіграфи перед другим розділом з метою зобразити реальність двома способами - прозаїчно (статистика) й поетично. Задум автора проявляється в доповненні статистичних даних поетичним світосприйманням при зображенні долі конкретної людини - Сари Вудраф. Емотивність досягається за допомогою зображення сумної долі дівчат. Два мікротексти у вигляді епіграфів формулюють лейтмотив другого розділу - незавидне положення самотніх дівчат, які в стані розпачу поводяться нерозважливо. Громада нехтує ними й уникає їх, наприклад, Эрнестина, подружка Чарлза, просить його повернути назад, щоб уникнути зустрічі із Сарою: Please let us turn back.

У поетичному епіграфі присутні дві концептуальні метафори «ВІТРИЛО КОРАБЛЯ ЦЕ ВІКТОРІАНСЬКА ЕПОХА» схвалює цінності Вікторіанської епохи, чекає світле майбутнє, а той, хто орієнтується на минуле, буде шкодувати про це. У другому розділі емотивний аспект ситуації представлено категорією «розчарування».

Висновки. Таким чином, особливістю роману Джона Фаулза «Жінка французького лейтенанта» $\epsilon$ емотивно навантажені епіграфи. Під лінгвоемотивною моделлю тексту розуміються характеристики фрагмента тексту й комунікативної ситуації, виражені умовами спілкування (місце, час, склад комунікантів) і параметрами комунікації (комунікативна установка й ціль, характер спілкування, 
вербальні й невербальні засоби, реакція адресата й адресанта). Теми епіграфічних текстів прояснюються після ознайомлення 3 текстом роману. Емотивна оцінка ситуації за допомогою лінгвістичних засобів розширює зміст тексту.

У перспективі дослідження слід направити на побудову лінгвоемотивних моделей тексту з використанням цитат, афоризмів, алюзій, паремій, топонімів, епонімів і ремінісценцій у романах Джона Фаулза.

\section{СПИСОК ВИКОРИСТАНИХ ДЖЕРЕЛ}

1. Богуславская В. В. Моделирование текста: лингвосоциокультурная концепция Анализ журналистских текстов: монография. Москва, 2008. 280 с.

2. Большой психологический словарь / ред. Б. Г. Мещеряков, В. П. Зинченко. СПб, 2005. $672 \mathrm{c}$.

3. Волкова Я. А. Параметры деструктивного общения в неэкологичной коммуникации // Человек в коммуникации: от категоризации эмоций к эмотивной лингвистике: сб. научных трудов. Волгоград, 2013.370 с. С. 317-323.

4. Волкова Я.А. Деструктивное общение в когнитивно-дискурсивном аспекте : монография. Волгоград, 2014. 324 с

5. Денисов П. Н. Принцип моделирования языка. Москва, 1965. 208 с.

6. Ларкин В. С. Эпиграф как элемент кодирования смысла художественного текста: на материале романа В. Скотта "Айвенго": дис. ... канд. филол. Наук : 10.02 .04 Москва, 2009. 212 с.

7. Лотман Ю. М. Внутри мыслящих миров. Человек - текст - семиосфера - история. Москва, 1999. 464 с.

8. Марчук Ю. Н. Методы моделирования перевода. Москва, 1985. 200 с.

9. Маслова В.А. Современные лингвистические направления: методические рекомендации. 2003. 37 c. URL: https://lib.vsu.by/xmlui/bitstream/handle (дата звернення: 21.10.2019).

10.Олешков М. Ю. Моделирование коммуникативного процесса : монография. Нижний Тагил, 2006. 336 с.

11. Самохина В. А., Рыжкова В. В. Интертекстуальность в диалогическом пространстве англоязычного художественного текста : монография. Харьков, 2017. $168 \mathrm{c}$.

12. Фрумкина Р. М. Психолингвистика: учеб. пособие для студ. высш. учеб. заведений. Москва, 2003. 320 c. URL: http://pedlib.ru (дата звернення 19.04.2019).

13. Шаховский В. И. Диссонанс экологичности в коммуникативном круге: человек, язык, эмоции. Волгоград, 2016. 504 с.

14. Шаховский В. И. Когнитивная матрица эмоционально-коммуникативной личности // Вестник РУДН. Серия: Лингвистика. Том 22, № 1. Дискурс эмоций. 2018. С. 54-79. URL: http://journals.rudn.ru/linguistics (дата звернення 13.04.2019).

15. Шаховский В. И. Лингвистическая теория эмоций. М.: Гнозис, 2008. 416 с.

16. Шаховский В. И. Эмоции: Долингвистика, лингвистика, лингвокультурология. URSS. 2010. $128 \mathrm{c}$.

17. Языкознание: большой энциклопедический словарь / гл. ред. В. Н. Ярцева. 2-е изд. Москва, 1998. 685 с.

18. Lakoff George. Language and Emotions. 2016. Volume: 8. Issue 3. P. 269-273.

19. Fowles John. The French Lieutenant's Woman. - Little, Brown and Company, 1969. $371 \mathrm{p}$.

\section{REFERENCES}

1. Bogyslavskaia, V.V. (2008). Modelirovanie teksta: lingvosotsiokylturnaia kontseptsiia. Analiz zhurnalistskikh tekstov: monographiia [Modelling of text: lingvosociocultural concept, Analysis of journalistic texts: manuscript]. Moskva: URSS. [in Russian]

2. Bolshoi psykhologicheskiy slovar (Comprehensive Psychological Dictionary) : red. B. G. Meshcheriakov, V. P. Zinchenko. Sankt Petersburg, 2005. 672 s. [in Russian] 
3. Denisov, P.N. (1965). Printsip modelirovaniia yazyka [Principle of language modelling]. Moskva: MGU. [in Russian]

4. Fowles John. (1969). The French Lieutenant's Woman. - Little, Brown and Company.

5. Frumkina, R.M. (2003). Psikholingvistika: uchebn. posobie dlia stud. vyssh. uchebn. zavedeniy [Psycholinguistics: coursebook for higher education institutions]. Moskva: Izdatelskiy tsentr Akademiia. [in Russian]

6. Lakoff, G. (2016). Language and Emotions. 8, 3, pp. 269-273.

7. Larkin, V.S. (2009). Epigraf kak element kodirovaniia smysla khudozhestvennogo teksta: na materiale romana W. Scott "Ivanhoe" [Epigraph as element to code the sense of fiction: on material of the novel Ivanhoe by W. Scott]: dissertatsiia kand. filol. nauk, 10.02.04 - Germanskie yazyki. Moskva [in Russian]

8. Lotman, Yu.M. (1999). Vnutri mysliashchikh mirov. Chelovek - tekst - semiosfera istoriia [Inside intelligent worlds. A human being - text - semiosphere - history]. Moskva: Yazyki russkoy kultury. [in Russian]

9. Marchuk, Yu.N. (1985). Metody modelirovaniia perevoda [Methods to model translation]. Moskva: Nauka. [in Russian]

10. Maslova, B.A. (2003). Sovremennye lingvisticheskie napravleniia : metodicheskie rekomendatsii [Modern linguistic directions : methodology recommendations]. $37 \mathrm{~s}$. [in Russian]

11. Oleshkov, M.Yu. (2006). Modelirovanie kommunikativnogo protsessa: monographiia [Modelling of communicative process: manuscript]. Nizhniy Tagil: NTGSPA. [in Russian]

12. Samokhina, V.O. (2016). Phenomen intertekstualnosti yak poliphonii tekstiv [Phenomenon of intertextuality as polyphony of texts]. In: Movy profesiinoi kommunikatsii: lingvokulturnyi, kohnituvno-dyskursyvnyi, perekladoznavchyi ta metodychnyi aspekty. Kyiv: Kefedra, s. 70-72. [in Russian]

13. Shakhovskiy, V.I. (2008). Lingvisticheskaia teoriia emotsiy [Linguistic theory of emotions]. Moskva: Gnozis. [in Russian]

14. Shakhovskiy, V.I. (2010). Emotsii: dolingvistika, lingvistika, lingvokulturologiia [Emotions: prelinguistics, linguistics, linguoculturology]. URSS. [in Russian]

15. Shakhovskiy, V.I. (2016). Dissonans ekologichnosti v kommunikativnom kruge: chelovek, yazyk, emotsii [Discord of ecological compatability in a communicative circle: person, language, emotions]. Volgograd: I.P.Polikarpov. [in Russian]

16. Shakhovskiy, V.I. (2018). Kognitivnaia matritsa emotsionalno-kommunikativnoy lichnosti [Cognitive matrix of an emotional and communicative personality]. Vestnik RUDN. Seriia: Lingvistika. - Bulletin of RUDN University. 22, 1, Diskurs emotsiy [Discourse of emotions], 54-79. [in Russian]

17. Volkova, Ya.A. (2013). Parametry destruktivnogo obshcheniia v neekologichnoy kommunikatsii. In: Chelovek v kommunikatsii: ot kategorizatsii emotsiy k emotivnoy lingvistike [Parameters of destructive communication in non-ecological communication. In: Person in communication: from categorization of emotions to emotive linguistics]: sbornik nauchnykh trudov. Volgograd: Volgogradskoe nauchnoe izdatelstvo. [in Russian]

18. Volkova, Ya.A. (2014). Destruktivnoe obshchenie v kognitivno-diskursivnom aspekte: monographiia [Destructive communication in cognitive-discursive aspect: manuscript]. Volgograd: Peremena. [in Russian]

19. Yazykoznanie : Bolshoy entsiklopedicheskiy slovar [Comprehensive Encyclopedic Dictionary] : gl. Red. V.N. Yartseva. - 2-e izd. - Moskva : Bolshaia Ros. entsyclopediia, 1998. - 685 s. [in Russian]

Received: 20 December, 2019 